\title{
What Drives International Competitiveness? An Empirical Test in Emerging Indonesian Market
}

\author{
- Prasetyo Heru Aries
}

\begin{abstract}
This study tried to identify factors which drive international sustainable competitive advantage using Indonesian listed-multinational companies. The study began with identifying the terminology for emerging market using a single index model. We then deployed the three measurements for competitive advantage which are return on sales, return on asset and return on equity. Our results showed that all three measurements have the power to explain each competitive factor for Indonesian multinational firm, but statistically, ROA showed as the best proxies. Moreover, eight out of ten hypotheses tested were strongly supported by the data. The study strongly emphasized the importance of knowledge management, local leadership and a factor of location as vital drivers for global competitive advantage. Lastly, the study also stressed the importance of globalizing subsidiaries in order to gain sustainable competitive advantage for the host country.
\end{abstract}

Keywords: competitiveness, multinational companies, firm performance, internationalization, emerging market, knowledge management

JEL Classification: M10, M16

\section{INTRODUCTION}

Having competitive advantage to compete globally is a must. Recent studies showed how companies tried to develop sustainable competitive advantage (Mihaela, 2016; Soliman, 2013; Srivastava et al., 2013; Cho \& Pucik, 2005; Offstein et al., 2005; Hafeez et al., 2003; Hennart \& Larino, 1998; Gomez-Mejia \& Palich, 1997). Some believe that a financial factor has contributed more to competitive advantage while others found the non-financial factors such as adaptability, cultural mixture, organizational structure, network, knowledge management and innovation important. That is why every organization needs to consider strategic management as an integrated policy which includes tangible and intangible assets.

Sustainable competitiveness started its origin with Barney (1991) and the most influential article. By examining the real phenomenon due to firm's limited resource, Barney had raised the importance of having something that is non-replicable by others - later known as competitive advantage. Some researchers have extended the concept gradually. Competitiveness that once was abstract now has become a famous object for the quantitative analysis. Return on Asset, Return on Equity and Return on Sales started to be acknowledged as the ideal measurements for competitive advantage (Becker-Blease et al., 2005; Merikas et al., 2006; Agiomirgiannakis et al., 2006; Bobillio et al., 2006; Laisasikorn \& Rompho, 2014).

However, though it has been analyzed widely, there is still no common conclusion among the competitive measurement and the indicators used (Powell, 2001; Lin \& Huang, 2011). Another progress of the study on related topic is that it encompasses several disciplines, including psy- 
chology, economy and international business management. Today, researchers pay more attention to multinational companies, since its profitability have strong contribution to home country economics performance (Feldstein et al., 1995; Baldwin \& Winters, 2004; Jones, 2010; Rugraff $\&$ Hansen, 2011). Therefore, governments try to promote globalization among domestic companies, including those who operate on emerging markets.

Unfortunately, research on multinational competitive factors for emerging market is still inclusive. Therefore, this paper has been designed to propose and examine an adequate framework of multinational company's competitiveness factors in order to be the best benchmark for practical terms and theoretical development. Using a sample from Indonesian listed company, the study tried to find a clearer evidence of possible factors that drive competitive advantage, especially those who operate on high systematic risk.

The structure of the paper is as follows: section two provides discussion on literature review used to develop the hypotheses. Section three explains the research methodology used to perform the empirical test. Section four describes the findings and discussion, while section five concludes the findings.

\section{LITERATURE REVIEW}

This section will briefly discuss several theories related to competitive advantage to develop a framework and a hypothesis.

\subsection{Competitive Advantage}

The term of competitive advantage has now become widely used. The term was first used by Ansoff (1965) as unique opportunities within a company's field of operation which proxies by the product-market scope and the growth vector. In its early phase, Porter (1985) suggested a clearer insight on competitiveness. By introducing five forces, Porter highlighted the importance of something that outperforms its competitors so that the company might have better power to control the market. Many companies to achieve better performance then commonly used this definition.

Moreover, Porter also proposed new terms of generic-strategy as the vital outcome for competitive advantage, which consist of cost leadership and differentiation. Though the concept seems logically accepted, some research tried to extend the concept to learning-organization (Teece, 1986; Farukh \& Waheed, 2015) and also organizational-capital (Tomer, 1987; Treleaven, 2004).

The second development phase was indicated by intra-field studies on competitive advantage. A psychological perspective had seen competitiveness as philosophy of setting the right position within competition in which victories are better achieved (Polyhart \& Hale, 2014; Schulte et al., 2009). Meanwhile, information system field of studies had related firm's competitiveness to knowledge management system. Gold et al. (2001) had succeeded in building fundamental perspective that sustainable competitive advantage is a measurable thing. By relating a knowledge management system, the study can explain how company might achieve better competitiveness on sequential basis. This meant the starting point of the era of quantifying competitive advantage and defined it as firm-performance. 
From international business perspective, competitive advantage is complementary to comparative advantage (Gupta, 2009; Lattimer, 2003), even within the context of Porter's concept. Superior un-imitable skills might come from the comparative point of view. For example, having loyal high-quality skilled personnel can contribute a lot to firm abnormal return (Tamkin, 2005; Wood, 1999). Another example would be having an organizational structure that fits in with knowledge technology infrastructure. Combining tangible and intangible assets effectively may create sustainable competitive advantage (Prasetyo et al., 2016).

Dealing with a competitiveness factor for a multinational company would be more complex compared to a domestic business entity. Factors such as business culture, technological constraints, regulation and other stakeholder's interest might play an important role. Differences between home and the host countries are also counts as major obstacles. Therefore, some companies retrieve themselves by closing its foreign subsidiaries and replace with joint venture or even by utilizing local agent (Bloomberg, 2015).

\subsection{Indicators and antecedents}

\subsubsection{Indicators of competitive advantage}

Relating sustainable competitive advantage to firm performance is possible since both of them are addressing the same concern (Krause et al., 2014). Using accounting variable on performance, we might depict Return on Sales, Return on Asset, Return on Equity and Return on Investment, in which every ratio shared different perspective and sometimes different signs. Return on Sales showed how much the company earned from its current sales. Higher efficiency represented by higher ROS (Ross et al., 2016) shows the capability of management to operate in such effective way to deal with limited resources and come up with a better outcome. In some literature, return on sales also known as gross profit margin ratio can be calculated as income before interest and taxes divided by sales.

The second and popular measurement for profitability would be Return on Asset. As developed by DuPont in 1919, return on asset explained how well the company utilized its overall asset in order to achieve a better income. Instead of its popularity, ROA shared limitations especially from a shareholder's perspective. Return on asset only use income after tax divided by a total asset. Meanwhile, there is a portion of shareholder's capital inside the number. Therefore, Madura (2015) explained that taking merger and acquisition concern into asset acquiring techniques, another shareholder's portion of capital must be acknowledged as possible alternative for profitability.

Dealing with those weaknesses, we then retrieve the third formulas, namely Return on Equity. ROE can be calculated as income after tax divided by book value of a shareholder's equity. The ratio determined how much income can be generated from the capital invested. A higher return on equity shows higher capability from company's management to manage the invested fund.

\subsubsection{Antecedents of competitive advantage for multinational firm}

Former researches had identified several antecedents of sustainable competitive advantage for multinational-operated companies (Wingwon \& Piriyakul, 2010; Hitt et al., 2006; Carpenter \& Sanders, 2004; Delgado-Gomez et al., 2004; Denis et al., 2002). The first factor relates to com- 
pany's creditworthiness in foreign countries. As consequences of operating on a foreign country, mostly, government policy required every company to use local funds as a source of financing. Though an increase level of debt might affects firm's risk, but the interest rate is a tax deductible and lower than cost of equity. At this point, subsidiaries may use debt to finance the investment activity in host country. This is best represented at firm's leverage ratio.

The second factor relates to haw fast a company can fulfill the capital needs. Once a company can achieve its optimum leverage over the long-run, then the true challenge could be found on how efficient their working capital. In term of accounting measure, this factor can be calculated by ratio of fixed assets to total asset. The ratio showed an inefficient use of working capital that tends to maintain cash on targeted minimum level. This capability is needed, since subsidiaries are required to response to any local-changing business and economic environment.

Efficient working capital represents high liquidity. It will determine company's ability to meet its short-term obligation using cash or asset that can be converted into cash immediately. Having an advanced mechanism to provide cash from daily sales, account receivable or sales of unproductive asset can increase company's competitive advantage.

The fourth antecedent is the size of company. Denis et al., (2002) argue that since the company can identify a maximum cash level within each period, then excess cash should be allocated not to current asset only but also to fixed assets which might create the opportunity for future expansion. Recently, there is financial indicator to measure a size which derived from asset, sales, or even number of employee. A bigger size compared to the other local player representing the strength of the company to increase their market share. It is also addressing the competitive power within industry. Therefore, investors used the indicator to estimate the company's bargaining power in industrial rivalry.

Furthermore, a bigger asset (or size) might relate to higher complexities. The company must be able to manage the level of productivity for each asset and this would require strong knowledge (whether in terms of formal or tacit-knowledge). The fifth antecedent related to Gold et al., (2001). As a vital mechanism to manage the innovation process - especially in dealing with higher complexities, knowledge management was believed to form the competitive advantage. A productive knowledge management system might produce product innovation that might fit with market expectation. This is the firmly basic for scholars who related KM system to research and development expense.

Another potential antecedent is the management competence index. As the KM system began to operate effectively, there should be significant improvement in personnel capabilities. Merikas et al. (2006) used the index to represents the role of intangible asset in company's competitive advantage. The idea was drawn from how a firm produced innovation (Chen \& Huang, 2007). Therefore, higher index determined high potential for sustainable competitive advantage. Moreover, human factor also affected cultural adaptation in subsidiaries. Similarity between a host and home country shared less complexity compared to totally different values. Over the long run, this might impact the ability of multinational company to gain competitive advantage. Therefore, we also posed the factor of location as one of potential factor for multinational competitive advantage. 


\section{RESEARCH METHOD}

This section describes data collection, variable identification and a proposed research model used in the study.

\subsection{Data collection}

The study used all Indonesian listed companies as population. Up to early 2016, the total number of public companies was 525, while 3 of them listed its preferred stock. We then analyzed each company's annual report to identify its worldwide operation and number of parent's agent and subsidiaries in different countries. The term multinational company for this study was referring to Rugraff and Hansen (2011) which stated that the organization must operate in at least two countries. After considering each criteria and information availability, we have samples of 217 companies. We then implemented the third filtering process by measuring company risk level using a single index model, since the study focused only in high emerging market.

For risk level categorization, we used Prasetyo (2011) to indicate companies who have systematic risk above 0.6 which define as those who operate on high emerging market. The latest criteria resulted on 147 companies. Moreover, the study comprised a longitudinal study from 2004 to 2014. Each sample was then observed during 2004-2014 and resulted on 1617 observations. The distribution of the sample can be seen in Figure 1.

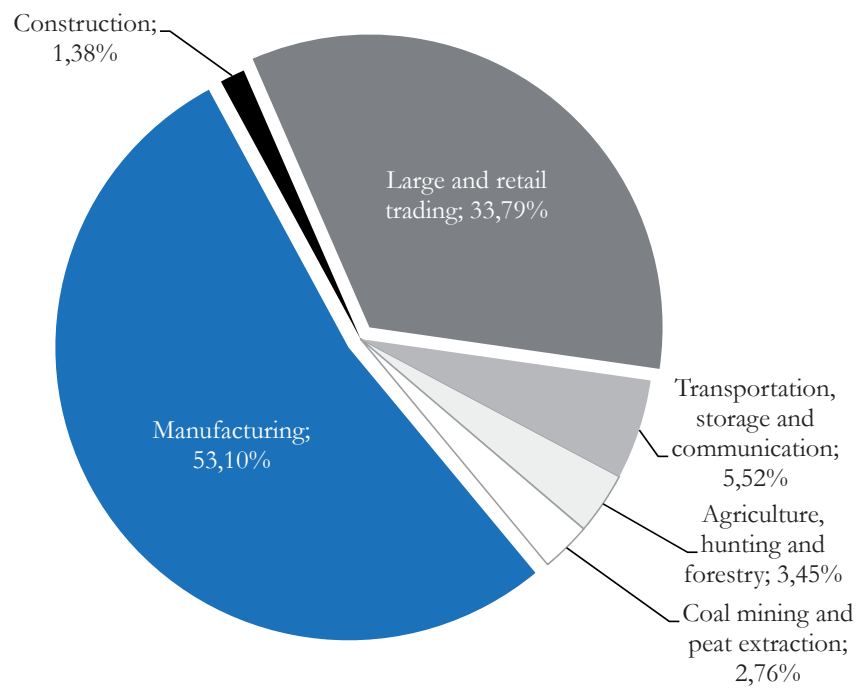

Fig. 1 - Sampling distribution. Source: Own research

\subsection{Variables}

The study used three independent variables as proxies of competitive advantage; return on sales, return on asset and return on equity, and treated them separately. This is to identify the ideal 
measurement for multinational company competitive advantage. Those which have better explanation power $\left(\mathrm{R}^{2}\right)$ can be acknowledged as the ideal proxies of multinational company's competitive advantage.

Moreover, drawing back from the theoretical framework discussed in section two, we use nine independent variables which considered both tangible and intangible factors. For a tangible factor, the first independent variable is leverage ( $L e v)$ which denotes as lag leveraged, measured by $(\operatorname{Lev}(-1))$. The second variable is working capital ratio (WCR). The third variable is company's size, measured by natural logarithm of total asset (Lnsize). The fourth variable is capital efficiency, proxies by fixed asset to total asset ratio (FATA), while the fifth variable is investment ratio (Netinv).

For the intangible factors, we use knowledge management as proxies by R\&D expenses to sales ratio $(K M)$ and natural logarithm of management competitive index $(L n C I)$, measured by net profit divided by number of expert for specific education level. We also control two dummy variables for Leadership pattern and firm's regional operation. Leadership pattern (Lead) omitted as 1 if the subsidiaries hired local professional in their organizational structure, and 0 if they are not. Meanwhile, firm's regional operation (Floc) was omitted as 1 if the company main operation was based in Asia's country and 0 if they operated in non-Asia's country.

We then choose the panel regression model to examine three independent variables on the same set of explanatory variables, while for each competitive advantage factor, the technique of panel least squares regression was applied to estimate the multiple regression coefficient $\left(b_{j}\right)$. The proposed equation models are as follows:

$$
Y=f(x)
$$

$\mathrm{Y}($ performance $)=\mathrm{f}$ (leverage, working capital, size, efficiency, investment, knowledge management, competitive index, leadership, location)

Considering all variables identified from the previous section, the function can be written as

$$
Y_{t}=a_{0}+b_{1} X_{1}+b_{2} X_{2}+b_{3} X_{3}+b_{4} X_{4}+b_{5} X_{5}+b_{6} X_{6}+b_{7} X_{7}+b_{8} X_{8}+b_{9} X_{9}+e_{t}
$$

Putting all variable into equation, then we will have:

$$
\begin{aligned}
& Y_{t}(\text { competitive advantage })=a_{0}+b_{1} X_{1}(\operatorname{Lev}(-1))+b_{2} X_{2}(\text { WCR })+b_{3} X_{3}(\text { Lnsize })+b_{4} X_{4}(\text { FATA })+ \\
& b_{5} X_{5}(\text { Netinv })+b_{6} X_{6}(\text { KM })+b_{7} X_{7}(\operatorname{LnCI})+b_{8} X_{8}(\text { Lead })+b_{9} X_{9}(\text { Loc })+e_{t}
\end{aligned}
$$

Since we have three indicators for competitive advantage, then each model can be written as follows:

$$
\begin{aligned}
& Y_{t}(\mathrm{ROS})=a_{0}+b_{1} X_{1}(\operatorname{Lev}(-1))+b_{2} X_{2}(\text { WCR })+b_{3} X_{3}(\text { Lnsize })+b_{4} X_{4}(\text { FATA })+b_{5} X_{5} \text { (Netinv) } \\
& +b_{6} X_{6}(\mathrm{KM})+b_{7} X_{7}(\mathrm{LnCI})+b_{8} X_{8}(\mathrm{Lead})+b_{9} X_{9}(\mathrm{Loc})+e_{t} \\
& Y_{t}(\mathrm{ROA})=a_{0}+b_{1} X_{1}\left(\text { Lev (-1)) }+b_{2} X_{2}(\text { WCR })+b_{3} X_{3} \text { (Lnsize }\right)+b_{4} X_{4}(\text { FATA })+b_{5} X_{5} \text { (Netinv) } \\
& +b_{6} X_{6}(K M)+b_{7} X_{7}(\operatorname{LnCI})+b_{8} X_{8}(\text { Lead })+b_{9} X_{9}(\text { Loc })+e_{t} \\
& Y_{t}(\mathrm{ROE})=a_{0}+b_{1} X_{1}(\operatorname{Lev}(-1))+b_{2} X_{2}(\text { WCR })+b_{3} X_{3}(\text { Lnsize })+b_{4} X_{4}(\mathrm{FATA})+b_{5} X_{5} \text { (Netinv) } \\
& +b_{6} X_{6}(K M)+b_{7} X_{7}(\text { LnCI })+b_{8} X_{8}(\text { Lead })+b_{9} X_{9}(\text { Loc })+e_{t}
\end{aligned}
$$


We hypothesize that each independent variables contributed to a multinational company's competitive advantage. The proposed hypotheses are as follows:

H1: Leverage $\left(\mathrm{X}_{1}\right)$ is contributes positively to multinational company's competitive advantage

H2: Working capital $\left(\mathrm{X}_{2}\right)$ is contributes positively to multinational company's competitive advantage

H3: Size $\left(\mathrm{X}_{3}\right)$ is contributes positively to multinational company's competitive advantage

H4: Efficiency $\left(\mathrm{X}_{4}\right)$ is contributes positively to multinational company's competitive advantage

H5: Investment $\left(\mathrm{X}_{5}\right)$ is contributes positively to multinational company's competitive advantage

H6: Knowledge management $\left(\mathrm{X}_{6}\right)$ is contributes positively to multinational company's competitive advantage

H7: Management competitive index $\left(\mathrm{X}_{7}\right)$ is contributes positively to multinational company's competitive advantage

H8: Leadership $\left(\mathrm{X}_{8}\right)$ is contributes positively to multinational company's competitive advantage

H9: Location $\left(\mathrm{X}_{9}\right)$ is contributes positively to multinational company's competitive advantage

Meanwhile, a hypothesis 10 deals with the joint influence of the nine variables on multinational company's competitive advantage.

\section{FINDINGS AND DISCUSSION}

\subsection{Findings}

The statistic descriptive for all three models can be seen in Table 1. The total number of observation is 1,617 using 147 companies. Meanwhile, the greatest standard deviation from the sample was identified on lag leverage and working capital as proxies by working capital ratio. One possible cause is that several companies had negative working capital, indicates that the amounts of current liability is bigger than current assets.

Tab. 1 - Descriptive statistic. Source: Own research

\begin{tabular}{|l|c|c|c|c|c|}
\hline & N & Minimum & Maximum & Mean & Std. deviation \\
\hline ROS & 1617 & -13.31 & 41.40 & .23 & 4.38 \\
\hline ROA & 1617 & -1.02 & .75 & .08 & .11 \\
\hline ROE & 1617 & -35.53 & 133.41 & .26 & 12.41 \\
\hline LEV & 1617 & -74.12 & 339.11 & .07 & 94.92 \\
\hline CR & 1617 & .00 & 278.71 & 4.456 & 72.29 \\
\hline
\end{tabular}




\begin{tabular}{|l|c|c|c|c|c|}
\hline LNSIZE & 1617 & 23.65 & 31.70 & 27.09 & 1.52 \\
\hline FATA & 1617 & .00 & 10.11 & .58 & .48 \\
\hline Netinv & 1617 & -15.94 & 5.65 & .08 & .62 \\
\hline KM & 1617 & .00 & .06 & .02 & .01 \\
\hline LnCI & 1617 & -1.55 & 1.67 & .30 & .41 \\
\hline Lead & 1617 & .00 & 1.00 & .90 & .30 \\
\hline Loc & 1617 & .00 & 1.00 & .76 & .43 \\
\hline Valid N (listwise) & 1617 & & & & \\
\hline
\end{tabular}

The regression result for the three models can be seen in Table 2. Referring to the table, all three models has the power to explain competitive advantage factors for a multinational company on emerging country (model $1 \mathrm{R}^{2}=16.50 \%, \mathrm{p}<0.05$; model $2 \mathrm{R}^{2}=23.94 \%, \mathrm{p}<0.05$; model $3 \mathrm{R}^{2}=$ $2.15 \%, \mathrm{p}<0.05)$. This may imply that we support hypothesis 10 which declared that all independent variables within a model can best explain competitive advantage, even though a model 3 has a very small explanatory power. But since the p-value was statistically significant, then we might support hypothesis 10 .

The comparison among models shows that the most explainable model is the one that used a Return on Asset as proxies of competitive advantage (model 2). Thus, we might say that for Indonesian multinational companies the best proxies for competitive advantage is a Return on Asset. We will describe the findings further in the discussion part.

Another finding from Table 2 is that our second model also shared the most significant independent variable. From nine-tested independent variables, this model can found seven variables which represent a high statistical-evidence thus, leaving the other two.

Tab. 2 - Regression results. Source: Own research

\begin{tabular}{|l|c|c|c|}
\hline Variable & Model 1 & Model 2 & Model 3 \\
\hline Dependent & $\begin{array}{c}\text { Return on } \\
\text { Sales }\end{array}$ & $\begin{array}{c}\text { Return on } \\
\text { Asset }\end{array}$ & $\begin{array}{c}\text { Return on } \\
\text { Equity }\end{array}$ \\
\hline Constant) & 1.040 & 0.349 & -5.321 \\
Leverage & $(1.833)$ & $(0.045)$ & $(5.784)$ \\
\hline Working capital & 0.001 & 0.012 & $0.017 *$ \\
\hline Size & $(0.001)$ & $(0.008)$ & $(0.003)$ \\
\hline \multirow{2}{*}{ Capital efficiency } & 0.001 & 0.001 & 0.001 \\
& $(0.001)$ & $(0.002)$ & $(0.004)$ \\
\hline
\end{tabular}




\begin{tabular}{|l|c|c|c|}
\hline Investment & $\begin{array}{c}2.768^{*} \\
(0.163)\end{array}$ & $\begin{array}{c}0.018^{*} \\
(0.004)\end{array}$ & $\begin{array}{c}0.075 \\
(0.501)\end{array}$ \\
\hline \multirow{2}{*}{ Knowledge management } & 2.406 & $8.731^{*}$ & 6.693 \\
\hline \multirow{2}{*}{ Management competitive index } & $(1.962)$ & $(0.474)$ & $(6.210)$ \\
\hline \multirow{2}{*}{ Leadership } & $1.084^{*}$ & $0.024^{*}$ & 1.098 \\
\hline \multirow{2}{*}{ Location } & $(0.245)$ & $(0.006)$ & $(0.751)$ \\
\hline $\mathrm{N}$ & 0.021 & $0.017 *$ & 0.238 \\
\hline $\mathrm{R} 2$ & $(0.339)$ & $(0.008)$ & $(0.042)$ \\
\hline
\end{tabular}

As the results clearly showed, the study supported hypothesis 1 (only for the third model), hypothesis 3 (only for the second model), hypothesis 4 (only for the second model), hypothesis 5 (for the first and second model), hypothesis 6 (only for the second model), hypothesis 7 (for the first and second model), hypothesis 8 (only for the second model) and hypothesis 9 (also only for the second model). The study failed to support hypothesis 2 for all models. This implies that working capital might not be the best driver for sustainable multinational competitive advantage. In fact, excluding the working capital variable from the model only increased the (R2) $1.7 \%$, while still maintaining the significances of the model $(\mathrm{p}<0.05)$.

\subsection{Discussion}

Our results shared several important contributions to the field of knowledge at the scope of multinational companies. A first contribution related to the ideal proxies for sustainable competitive advantage. Though several studies succeeded in proposing another alternative as proxies of long term performance (Damodaran, 2009; Tangen, 2004), our result give strong emphasis to Hegel et al., (2013); Schiefer et al., (2013); Dehning \& Stratopoulos (2003); and Davis et al., (2002). For most subsidiaries which operated in a foreign country, performance measurement relied on asset utilization. This is true due to the obligations to use local debt financing as required by the host government. However there is a logical systematic reasoning in which investors tend to analyze financial performance on parent-subsidiary basis. Therefore, return on equity will likely more appropriate to the parent's perspective, while asset utilization might represent subsidiary's potential future growth.

Our research also succeeded in finding new evidence of working capital as drivers for multinational competitive advantage. One challenge for operating outside home country is how to compete with all local players. This might reflect a mid-term dynamic force (Mark, 2000) in which company must be able to adapt faster, both to the government regulation and also market demand. This condition requires strong debt financing which mostly comes from the local banking (Madura, 2015). 
Incorporating use of a short-term local debt, especially for asset acquiring investment purposes must be understood as a basic component for competitive advantage. This has been proven by hypotheses 3 to 5 . The positive signs of size, capital efficiency and investment showed that management of multinational companies must create a unique-decentralized mechanism which allows each division to make some tactical decision. The reason is that decentralization might spare opportunity to achieve better efficiency in terms of local economy performance (Nita \& Dura, 2011).

The second unique contribution of the study is due to the role of knowledge management for multinational companies. As proposed by Gold et al., (2002), knowledge management is an integrated system that provides ability to formulate inimitable idea for future innovation. Retrieving that the process of producing innovation lay on research and development activity, it is then plausible to adhering company's investment in R\&D and its relations with sales.

However, within the concepts of decentralization, most parents give authority to subsidiaries to have its own R\&D investment budget. This might trigger subsidiary's knowledge management system to provide more influence on local society (Guimon, 2008; Mudambi \& Mudambi, 2005). Today, one of the primary reasons for host government to have more foreign direct investments is due to the needs to update local's knowledge. Over the long run, the process might share direct impact on the nation's competitiveness (Porter, 2001).

A multinational company found to have a great role from nations point of view, since it implies systematic knowledge transfer mechanism from a home country to a host country. One fine example could be retrieved from a corporate environmentalism movement. Prasetyo et al. (2016) found out that the motives for engaging in eco-friendly business come from the economic collaboration with a high level of environmental-awareness country. Mostly, the parent company will force the subsidiaries to be able to become the first mover for green business. Through a proper human resource strategy, professional exchange from a host to a home country might induce the paradigm effectively, thus soon creating a similar business spirit among the two.

From human capital perspective, a higher capability especially for subsidiaries' management team might be the underlying factor for sustainable competitive advantage. This is the third contribution from our study. This finding supports Barney and Wright (1997). Having considered that most governments are seeking ways to reduce an unemployment rate by inviting more foreign direct investment, therefore human development must be a pivotal issue. Our finding has included two aspects of humans: the role of knowledge management and management competitive index.

Referring to Merikas et al., (2006) who measured the index using profit divided by number of professional due to their educational background, the study suggested the importance of developing an internal training division to be corporate university for both parent and subsidiaries. Though it shared no formal degree, some Indonesian companies have already proved that changing the function of human resource to the vital moderator of knowledge management system might act as a better mechanistic way to combine all tacit and formal knowledge, thus increasing the index as crucial measurement of competitive advantage. 
Nonetheless, over the long run, the mechanism might create host country's future leaders effectively. This is the target of every nation (Clark, 2009; Bartlett \& Goshal, 2003; Winder, 2002). Our study confirmed the thoughts. A positive and significance evidence has been found among our sample. This implied the importance of providing a systemic mechanism which can nurture the local leadership.

Another unique contribution from the study is regarding the company's location aspects. It is proven that firms locating in Asia tend to contribute more to higher competitive advantage for a multinational firm. The most possible reason is a similarity of culture that makes adaptability process seem easier than to those of non-Asia's countries. Our findings supported Zvirgzde et al., (2013); Meyer and Nguyen, (2005); Resmini, (2002). A short implication for the practical term is that multinational companies must consider the role of culture in direct investment decisions.

An intimate culture among the countries within region might affect three pivotal factors: market perspective, investor and also local management. Our sample consists of subsidiaries with shared autonomy from the parents. Some functional decisions, such as marketing and human resource, have become a dominant issue for the subsidiary. Though the probability to fail in cultural mix is somewhat higher than the parent, but close-culture relationship might be the catalyst which minimize those potential conflicts. The finding supported Rozkwitalza (2009), McFarlin and Sweeny (2006) and Hofstede (1994).

From investors' point of view, having considered that investment and loan mechanism require the spirit of trust and honesty, similarity of culture signals another benefit. Some of our samples acknowledged the local bank relationship as their basis for future sustainability. This is true since each government had implemented investment policy which indicates the needs of using domestic capital. In the case when Indonesian interest rate is higher than the one of a host country, most likely the subsidiary can contribute more to their parent. Conversely, for the host country with a higher interest rate, an exchange rate stability would prefer as risk-mitigation so that in the final stage, financial consolidation tend to recover the losses and provide positive contribution.

Another impact of a cultural factor can be retrieved from customer's point of view. Our field analysis showed that Malaysian product tends to be more acceptable by the Indonesian, compare to Australian or New Zealand product. By acknowledging that the two nations come from the same Malay's descendant, the cultural sense succeeded in creating local embedders. The spirit of goodwill acts as a magnet for future loyalty.

Although it was proven empirically but investing outside Asia, it is still possible, especially in the free trade area. Our sample also indicated some companies which succeeded in dealing with European countries. Without prior investigation on related variable, further studies need to be developed by including another proxy for a cultural factor. 


\section{CONCLUSION}

The study succeeded in finding the evidence for multinational competitive advantage from emerging market. Using Indonesia listed companies, the study began with giving a clear insight to the terminology of emerging market. Having deployed a single index model as representing beta, our sample showed a strong positive contribution of working capital, size, capital efficiency, investment, knowledge management, local leadership and location to sustainable competitive advantage. Having tested the three measurements of competitiveness - ROS, ROA, ROE - we strongly suggest to use ROA as best proxies of competitive advantage, especially for multinational companies.

This study has limitations due to the definition of multinational company. A further research must be done to make a better definition of multinational by taking into consideration the multi stage mechanism to be a global company starting from export activity, marketing agent and fully managed subsidiaries. This can be accomplished by having more samples for each level to have a better explanation.

In practical terms, our finding suggests the importance of local people development and knowledge management system for a multinational company. The research shows that success in local people development process by enhancing the role of knowledge management would act as the pivotal point for international sustainable competitive advantage. Therefore, more attention should be paid to have a clear framework for future research in the same topics.

Another important issue would be addressing the role of culture as a mediator variable for both local people development and knowledge management. Though the two terms shared the same needs, our finding indicates that for a subsidiary which operates in a developed country or first tier economy in the region, similarity of values tend to be the key success factor for international sustainable competitive advantage.

\section{Acknowledgements}

The author gives appreciation to Professor Anthony Kuo from Fu Jen Catholic University and the two anonymous reviewers from Journal of Competitiveness for their great ideas and comments on the paper.

\section{References}

1. Agiomirgiannakis, G., Voulgaris, F,. \& Papadogonas, T. (2006). Financial factors affecting profitability and employment growth: The case of Greek manufacturing. International Journal Financial Services Management, 1(3), 232-242. doi:10.1504/IJFSM.2006.009628

2. Baldwin, R. E., \& Winters, L. A. (2004). Challenges to globalization: analyzing the economics. University of Chicago Press.

3. Barney, J. B., \& Wright, P. M. (1997). On becoming a strategic partner: the role of human resources in gaining competitive advantage. CAHRS working paper 97-09, Itacha, NY: Cornell University, School of Industrial and Labor Relations, Center for advanced human resource studies.

4. Bartlett, C. A., \& Ghoshal, S. (2003). What is global manager?. Harvard Business Review, August 
5. Becker-Blease J. R., Kaen, F. R., \& Baumann, H. (2005). An investigation of the small firm effect using accounting measures of profitability: Does it exist? Whittemore School of Business and Economics University of New Hampshire.

6. Bloomberg. (2015). Why Chevrolet can't crack Indonesia. Bloomberg Godfly, written by Mukherjee, A. Retrieved from http://www.bloomberg.com/gadfly/articles/2015-12-04/gms-chevy-shut-out-shows-indonesia-s-protectionist-tilt

7. Bobillo, A. M., Rodriguez Sanz, J. A., \& Gaite, F. T. (2006). Innovation investment, competitiveness and performance in industrial firms. Thunderbird International Business Review, 48(6), 867-890. doi:10.1002/tie.20126

8. Carpenter, M. A., \& Sanders, W. G. (2004). The effects of top management team pay and firm internationalization on MNC performance. Journal of Management. 30, 509-519. doi:10.1016/j.jm.2004.02.001

9. Cho, H., \& Pucik, V. (2005). Relationship between innovativeness, quality, growth, profitability and market value. Strategic Management Journal. 26(6), 555-575

10. Chen, C. J., \& Huang, J. W. (2007). Strategic human resource practices and innovation performance - the mediating role of knowledge management capacity. Journal of Business Research, 62, 104-114. doi:10.1016/j.jbusres.2007.11.016

11. Clark, G. (2009). Recession, recovery and reinvestment: the role of local economic leadership in a global business. Local Economic and Employment Development Program. OECD. Retrieved from https://www.oecd.org/cfe/leed/50394250.pdf

12. Davis, L., Dehning, B., \& Stratopoulos, T. (2002). Does the market recognize IT-enabled competitive advantage? Online Working paper University of New Hampshire, Durham, New Hampshire. Retrieved from http://citeseerx.ist.psu.edu

13. Dehning, B., \& Stratopoulos, T. (2003). Determinants of a sustainable competitive advantage due to an IT-enabled strategy. Journal of Strategic Information Systems, 12, 7-28. doi:10.1016/S0963-8687(02)00035-5

14. Delgado-Gomez, J. M., Ramirez-Aleson, M., \& Espitia-Esener, M.A. (2004). Intangible resources as a key factor in the internalization of Spanish firms. Journal of Economic Behavior and Organization, 53, 477-487.

15. Denis, D. J., Denis, D. K., \& Yost, K. (2002). Global diversification, industrial diversification and firm value. Journal of Finance, 57, 1951-1961. doi:10.1111/0022-1082.00485

16. Farukh, M., \& Waheed, A. (2015). Learning organization and competitive advantage: an integrated approach. Journal of Asian Business Strategy, 5(4), 73-80.

17. Feldstein, M., Hines, J. R., \& Hubbard, R. G. (1995). The effects of taxation on multinational corporations. University of Chicago Press.

18. Gomez-Mejia, L. R., \& Palich, L. E. (1997). Cultural diversity and the performance of multinational firms. Journal of International Business Studies, 28(2), 309-335.

19. Guimon, J. (2008). Government strategies to attract R\&D-intensive FDI. Global forum on international investment. OECD. Retrieved from http://www.oecd.org 
20. Gupta, S. D. (2009). Comparative advantage and competitive advantage: an economics perspective and a synthesis. Working paper, St. Thomas University Fredericton, N.B., Canada. Retrieved from http://economics.ca/2009/papers/05

21. Hafeez, K., Zhang, Y., \& Malak, N. (2002). Core competence for sustainable competitive advantage: A structural methodology for identification of core competences. IEE Trans Eng Management, 49, 28-35. doi:10.1109/17.985745

22. Hagel, J., Brown, J. S., Samoylova, T., \& Lui, M. (2013). Success or struggle: ROA as a true measure of business performance. Report 3 of the 2013 shift index series. Deloitte Centre for the Edge.

23. Hennart, J., \& Larino, J. (1998). The impact of culture on the strategy of multinational enterprises: Does national origin affect ownership decisions? Journal of International Business Studies, 29(3), 515-538. doi:10.1057/palgrave.jibs.8490005

24. Hitt, M. A., Tihanyi, L., Miller, T., \& Connelly, B. (2006). International diversification: antecedents, outcomes and moderators. Journal of Management, 32(6), 831-868. doi:10.1177/01 49206306293575

25. Hofstede, G. (1994). The business of international business is culture. International Business Review, 3(1), 98-112. http://dx.doi.org/10.1016/0969-5931(94)90011-6

26. Jones, G. (2010). Multinational strategies and developing countries in historical perspective. Working paper 10-076. Harvard Business School.

27. Laisasikorn, K., \& Rompho, N. (2014). A study of the relationship between a successful enterprise risk management system, a performance measurement system and the financial performance of Thai listed companies. Journal of Applied Business and Economics, 16(2), 82-94.

28. Lattimer, R. (2003). The new age of competitiveness. Competitiveness Review, 13(2), 139-152. doi:10.1108/eb046454

29. Lin, C. S., \& Huang, C. P. (2011). Measuring competitive advantage with an asset-light valuation model. African Journal of Business Management, 5(13), 5100-5108. doi: 10.5897/ AJBM.10.681

30. Madura, J. (2015). International financial management, 12th edition. Cengage Learning.

31. Mark, M. (2000). Globalization: trends, challenges and opportunities for countries in transition. United Nations, Industrial Development Organization

32. McFarlin, S. B., \& Sweeney, P. D. (2006). International management. Strategic opportunities and cultural challenges. Houghton Miffin Company, Boston, New York

33. Merikas, A. G., Merika, A. A., \& Skandalis K. S. (2006). An effective index of management competence. Paper presented at the 15th Annual Conference of European Financial Management Association, Madrid.

34. Meyer, K. E., \& Nguyen, H. V. (2005). Foreign investment strategies and sub-national institutions in emerging markets: evidence from Vietnam. Journal of Management Studies, 42(1), 63-93. doi:10.1111/j.1467-6486.2005.00489.x

35. Simionescu, N. (2016). The competition between London companies regarding their financial performance. Journal of Competitiveness, 8(2), 5-16. doi:10.7441/joc.2016.02.01 
36. Mudambi, R., \& Mudambi, S. (2005). Multinational enterprise knowledge flows: the effect of government inward investment policy. Management International Review, 45(2), 155-178. doi:10.1007/978-3-322-91003-5_8

37. Nita, D., \& Dura, C. (2011). Approaching competitiveness at the level of multinational companies. Anals of the University of Petrosani, Economics, 11(4), 223-232.

38. Offstein, E, H,. Gnyawali, D. R., \& Cobb, A, T., (2005). A strategic human resource perspective of firm competitive behavior. Human Resource Management Review, 15, 305-319. doi:10.1016/j.hrmr.2005.11.007

39. Ployhart, R. E., \& Hale, D. (2014). The fascinating psychological micro foundations of strategy and competitive advantage. Annual Review of Organizational Psychology and Organizational Behavior, 1, 145-172.

40. Porter, M. (2001). The competitive advantage of nations. Harvard Business Review, March-April.

41. Powell, T.C. (2001). Competitive advantage: logical and philosophical considerations. Strategic Management Journal, 22, 875-888. doi:10.1002/smj.173

42. Prasetyo, A. H. (2011). Systematic risk and capital structure in emerging Indonesia market. Proceedings International Conference on Business and Economics, Singapore

43. Prasetyo, A. H., Lo, W., \& Chang, A. (2016). Corporate environmentalism: dealing with myopic and future agenda. SSRN, available at http://ssrn.com/abstract $=2768552$

44. Resmini, L. (2000). The determinants of foreign direct investment in the CEECs: new evidence from sectoral patterns. The Economics of Transition, 8(3), 665-690. doi:10.1111/14680351.00060

45. Rugraff, E., \& Hansen, M. W. (2011). Multinational corporations and local firms in emerging economies. Amsterdam University Press.

46. Rozkwitalska, M. (2009). Cultural dilemmas of international management. Journal of Intercultural Management, 1(1), 91-99.

47. Ross, S. A., Westerfield, R.W., Jaffe, J., \& Jordan, B. D. (2016). Modern financial management, 8th edition, McGraw-Hill.

48. Schiefer, J., Hirsch, S., Hartmann, M., \& Gschwandtner, A. (2013). Industry, firm, year and country effects on profitability in EU food processing. Working paper, University of Kent, available at www.kent.ac.uk/economics/documents/research/papers/2013/1309.pdf

49. Schulte, M., Ostroff, C., Shmulyian, S., \& Kinicki, A. (2009). Organizational climate configurations: relationships to collective attitudes, customer satisfaction, and financial performance. Journal Applied Psychology, 94(3), 618-634. doi:10.1037/a0014365

50. Soliman, F. (2013). Does innovation drive sustainable competitive advantage? Journal of Modern Accounting and Auditing, 9(1), 130-143.

51. Srivastava, M,. Franklin, A., \& Martinette, L. (2013). Building a sustainable competitive advantage. Journal of Technology Management \& Innovation, 8(2), 148-164. doi:10.4067/S071827242013000200004 
52. Tamkin, P. (2005). Measuring the contribution of skills to business performance: A summary for employers. Institute for Employment Studies, Brighton, UK

53. Treleaven, L. (2004). A knowledge-sharing approach to organizational change: A critical discourse analysis. Organization as knowledge system, 154-180. New York, Palgrave Macmillan.

54. Winder, D. (2002). The roles of partnership and bridging leadership in building stronger communities. The Synergos Institute, New York, USA.

55. Wingwon, B., \& Piriyakul, M. (2010). Antecedents of PLS path model for competitive advantage and financial performance of SMEs in Thailand. African Journal of Marketing Management, 2(6), 123-135.

56. Wood, S. (1999). Human resource management and performance. International Journal of Management Review, 1(4), 367-413. doi:10.1111/1468-2370.00020

57. Zvirgzde, D,. Schiller, D., \& Diez, J. R. (2013). Location choice of multinational companies in transition economies: a literature review. Search working paper, WP2/05, Leibniz University Hanover.

\section{Contact information}

Aries Heru Prasetyo

Fu Jen Catholic University, Taiwan, R.O.C

510 Zhongzheng $\mathrm{Rd}$, Xinz̧huang District,

New Taipei City 24205, Taiwan, R.O.C

E-mail:justzhongshan@gmail.com 